\title{
Differences in growth parameters of Scots pine between Poland and Finland: a comparative study with reference to soil texture
}

\author{
Piotr Sewerniak* \\ Nicolaus Copernicus University, Faculty of Earth Sciences and Spatial Management, Department of Soil Science and Landscape Management, \\ Lwowska 1, 87-100, Toruń, Poland \\ * Dr hab. inż. Piotr Sewerniak, sewern@umk.pl, ORCID iD: https://orcid.org/0000-0002-3071-3963
}

Received: October 4, 2019

Accepted: March 16, 2020

Associated editor: J. Lasota

\section{Keywords}

Pine stands

Soil texture

Site index

Climate gradient

Forest management

Forest conversion

\begin{abstract}
The aim of the study was to compare the differences in growth parameters (height, diameter, site index) of Scots pine (Pinus sylvestris L.) stands in three regions located in different parts of the European pine limit (Wrocław, SW Poland; Kolari and Kevo, N Finland) with reference to soil texture. The detailed research conducted in the Wrocław region (349 plots) was confronted with preliminary results from Finland (18 plots). Despite the fact that the study was based on a relatively low number of plots for the Finnish regions, statistically different mean site index values between all the studied regions were found. The study determined also the magnitude of differences in height and diameter of pines being at the same age, but growing in various climatic regions of European pine limit. The effect of soil texture on site index of pine stands was found only for the Wrockaw region; however, it concerned ecosystems with sandy soils. For detail investigation of potential existence of the effect for pine ecosystems of northern Finland this preliminary study should be expanded to more research plots located in this zone. The results of this research suggest that in Central Europe Scots pine does not fully utilize the fertility of soils when grown on fine-textured pedons. Thus, such soils should be primarily designed for conversion of pine monocultures into broadleaved stands.
\end{abstract}

\section{Introduction}

Scots pine (Pinus sylvestris L.) is one of the most commercially important forest tree species in the world. This especially concerns Central and Northern Europe where in some countries, as e.g. in Poland and Finland, the species covers more than half of the total forest area (Sevola, 2013; Milewski, 2017). However, the relatively high share of Scots pine is the result of different reasons which are specific for the boreal and the temperate European region. In Northern Europe the predominance of conifers is mainly related to a natural agent, as it results primarily from climatic conditions. In turn, in Central Europe the high predominance of Scots pine is related to anthropogenic factors, because since turn of the 18th and 19th century the species has been introduced on huge areas of sandy as well as fine-textured soils which previously had been covered with broadleaved forests (Olaczek, 1976; Zerbe, 2002; Kint et al., 2006).

As a result of the high importance of the issue for forestry, the dissimilarities in growth parameters of Scots pine between different regions have been examined in many studies. They were also investigated with reference to climatic gradient (e.g.
Seo et al., 2010; Henttonen et al., 2014; Franke et al., 2017), because of the obvious and important effect of climate on the growth dynamics of trees. In these studies, traditionally, the importance of temperature and precipitation has been highlighted, the significance of which increases (temperature) or decreases (precipitation) with increasing latitude (Hustich, 1972).

The detailed knowledge about the effects of climate and soil conditions on growth dynamics of main commercial tree species is important not only from an economic point of view, but the issue also poses an ecologically important question. For example, in Central Europe, where in the past conifer monocultures were commonly planted on primarily sites of broadleaved species, recognition of the relationship between soil texture and pine dynamics is crucial for indicating areas in which conifer monocultures should be converted into deciduous stands. In turn, the conversion is highly postulated, because pine monocultures covering huge areas in the temperate European zone are labile and susceptible to hazards (e.g. Kenk and Guehne, 2001; Spiecker, 2003).

With regard to growth parameters of pine stands examined in relation to soil texture, so far the issue has been sep- 
arately studied for Polish forests (Sewerniak, 2011a) and for Finnish woodlands (Tamminen, 1993). Moreover, in the latter study only pine stands located in southern Finland were investigated, while northern parts of the country were neglected. The aim of this study is to compare the differences in growth parameters of Scots pine stands (height, diameter, site index) in three regions located in SW Poland and in N Finland with reference to soil texture.

\section{Materials and methods}

The study was conducted in three regions in Europe, which clearly differed in climatic conditions: 1 . the Wrocław region located in south-western Poland, 2. the Kolari and 3. the Kevo regions both located in northern Finland (Fig. 1). The first two regions (Wrocław and Kolari) are located within the natural range limit of Scots pine in Europe, while the Kevo region is located about $70 \mathrm{~km}$ further north than the continuous pine forest limit in Lapland (Hustich, 1958).

In total, 367 plots were investigated in the study (349 in the Wrocław region, 13 in the Kolari region, and 5 in the Kevo region). At each plot, the growth parameters (height and diameter at $130 \mathrm{~cm}$ above ground level) of pines, as well as soil properties were investigated. In the Wrocław region and in the Kolari region the study was conducted in even-aged production pine stands. The range of their age was 42-141 years for the Wroclaw and 78-95 years for the Kolari region. In these regions the top height of a pine stand was determined in each plot. The height was defined as the mean height of 10 the thickest pines growing in 0.1 hectares (Bruchwald and Kliczkowska, 1997). From these measurements, site index for the pine stand was calculated, which indicated the potential top height of a stand at the age of 100 years. For these calculations, the equation of Bruchwald et al. (2000) was applied for Polish stands, and of Gustavsen (1980) for the stands situated in the Kolari region. Besides heights, diameters of the 10 pines were measured in each plot.

In the Kevo region the studied pine woods were not evenaged stands, but all-aged, which were not subjected to forest management treatments. This involves that the methodology of tree measurements was different in the Kevo region. Namely, in each of the Kevo stands, a circular plot was established in which the height and diameter of all pines at least $1.5 \mathrm{~m}$ tall (251 in total) were measured. Furthermore, the age of each tree was determined by counting the tree-rings in cores extracted with an increment borer. The range of the age was 8-215 years. The area of circular plots varied from 0.03 to 0.08 hectares, and it depended on the density of the pine stand. The number of pines measured in a single plot in the Kevo region varied from 47 to 59. For each plot, linear regression was elaborated for the relationship between age and height of the pines, which showed the occurrence of the strong relation between the variables - values of coefficient of determination $\left(R^{2}\right)$ equalled from 0.58 to 0.94 . The equations were used to calculate model heights of the studied stands at the age of 100 years and the obtained values were treated as site index values for the studied Kevo pine stands.

In each plot located in Finland, a soil pit was dug and soil samples were collected to determine the content of particular textural classes. Particle-size distribution of each collected sample was examined by the combined sieve-hydrometer method (FAO 2015). The results of soil texture for the Polish plots were gained from Forest Sites Inventory Plans (Operat, 2003, 2004,
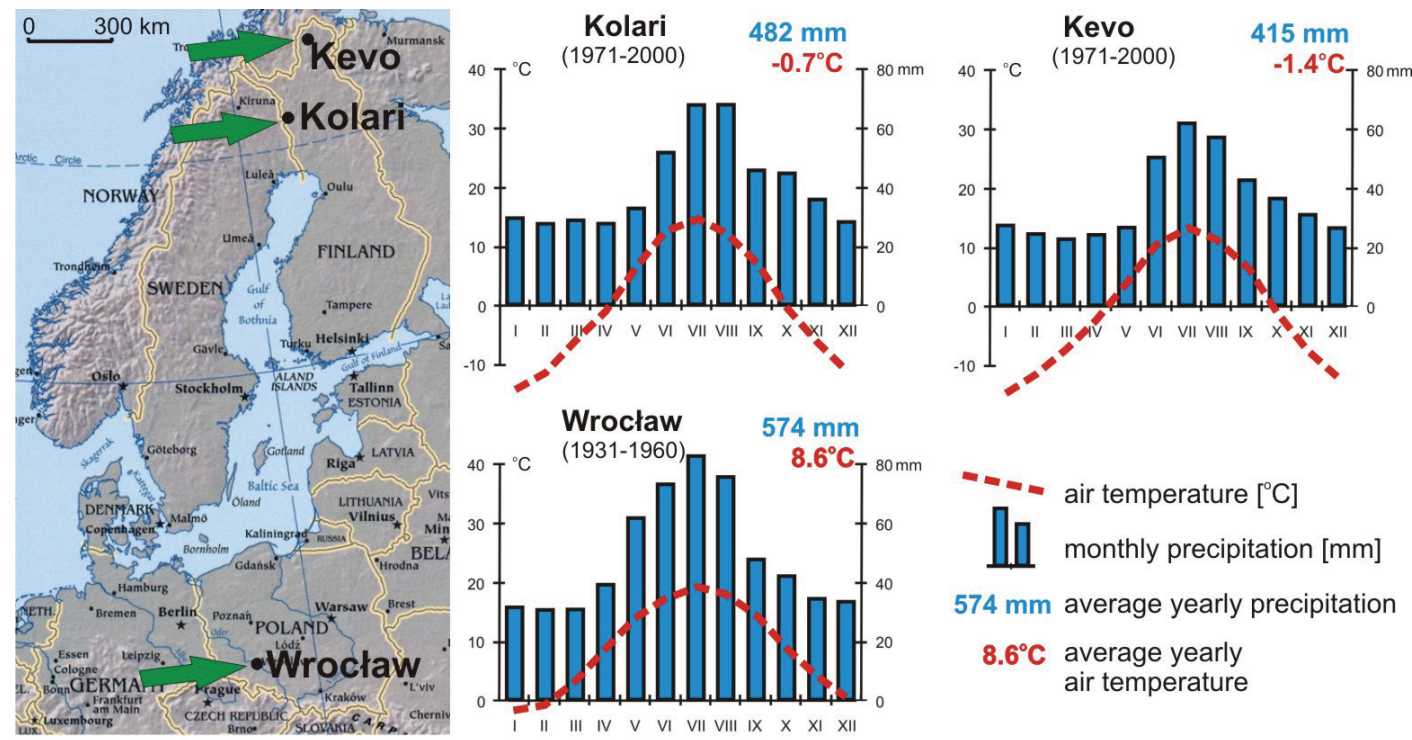

Fig. 1. Location and main climate characteristics of the investigated regions (climatic data gained from Woś 2010 and Finnish 2008-2009). Climatic data for Kolari are averaged records for meteorological stations in Muonio and Pello, which are situated ca. $65 \mathrm{~km}$ north and south to Kolari, respectively (direct climatic data for Kolar were not available) 
2005). In the elaborations the textural class $>1 \mathrm{~mm}$ was treated as soil skeleton, thus such approach was also applied for this study. Based on contents of the particular classes obtained for soil horizons as well as the thicknesses of the horizons, for each studied soil the mean weights of the classes were calculated for the whole soil profile (Table 1). This was done to facilitate investigating soils with regard to one value referring to a par- ticular soil texture class. Examples of soils and pine stands investigated in the studied regions are shown in figure 2.

The statistical analyses were performed in the STATISTICA 9.0 package. In the analysis of variance, the RIR Tukey test for uneven size samples was applied. The Spearman correlations were used to examine the relationships between site index values and contents of the investigated soil textural fractions.

Table 1

Mean weights $( \pm S D)$ of the main textural classes content for the studied soils by regions

\begin{tabular}{llll}
\hline \multirow{2}{*}{ Textural class } & \multicolumn{2}{l}{ Region } & Kolari \\
\cline { 2 - 4 } & Wrocław & $17.7 \pm 10.4$ & $25.6 \pm 25.1$ \\
\hline$>1 \mathrm{~mm}$ & $14.7 \pm 16.1$ & $76.9 \pm 9.6$ & $90.9 \pm 7.4$ \\
\hline $1-0.05 \mathrm{~mm}$ & $88.6 \pm 13.6$ & $21.1 \pm 9.0$ & $8.0 \pm 7.0$ \\
\hline $0.05-0.002 \mathrm{~mm}$ & $8.5 \pm 9.2$ & $2.0 \pm 1.0$ & $1.1 \pm 0.7$ \\
\hline$<0.002 \mathrm{~mm}$ & $2.7 \pm 6.0$ & &
\end{tabular}
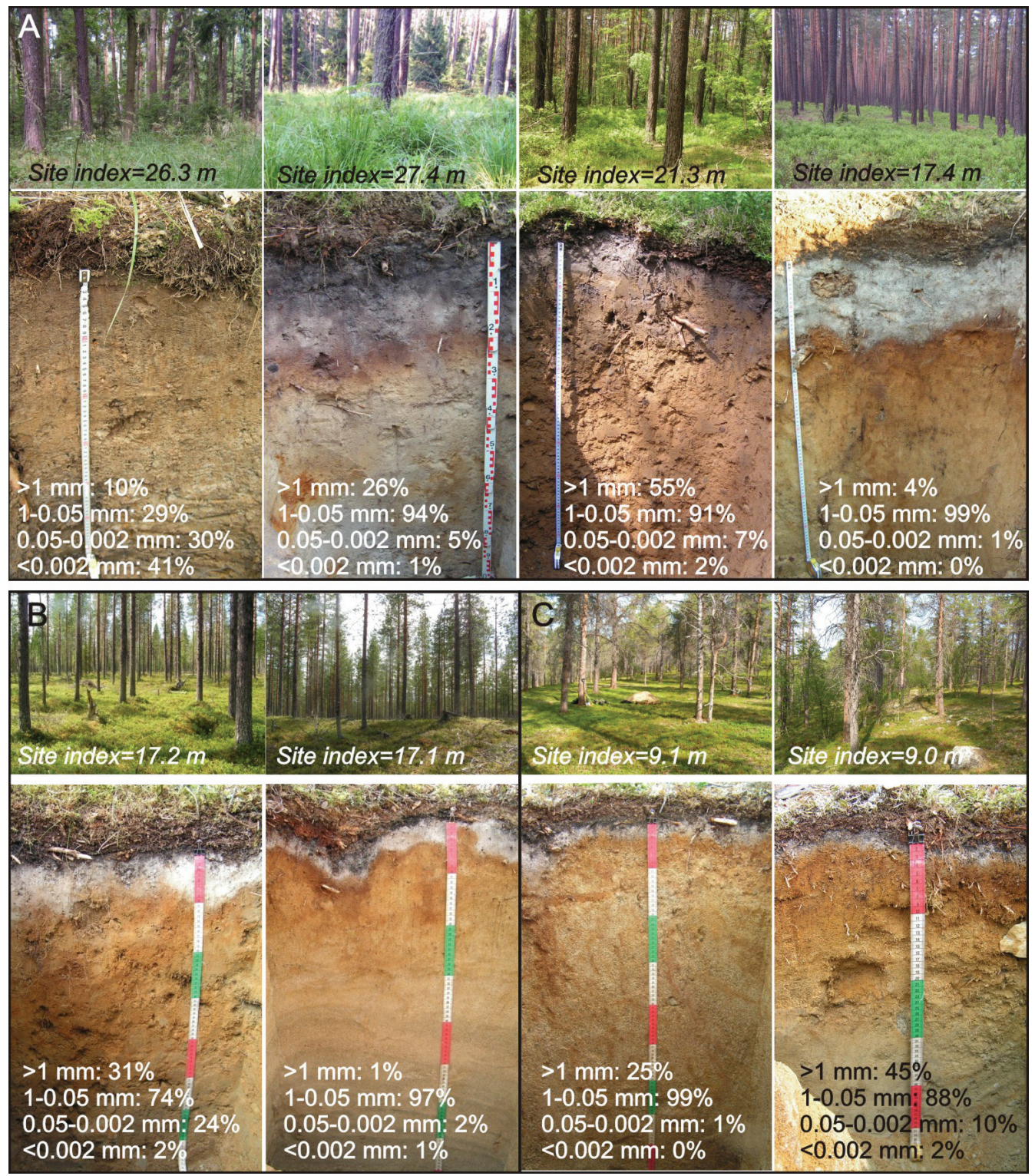

Fig. 2. Exemplary soils and pine stands of the studied plots. A - the Wrocław region, B - the Kolari region, $\mathrm{C}$ - the Kevo region. Percentage values given in a photo of a soil indicate weighted average content of some textural fractions for a soil profile 


\section{Results}

\subsection{Differences in growth parameters}

All the investigated growth parameters of pine stands (height, diameter, site index) were the highest in the Wrocław region, next in the Kolari region, and they were the lowest in the Kevo region (Figs 3 and 4). In plots in the Kolari area, mean height of the measured pines was $16.5 \pm 1.3 \mathrm{~m}$ and mean diameter $24.7 \pm 2.5 \mathrm{~cm}$. Compared to the same age range as pine stands in Kolari (78-95 years), trees investigated in the Wroclaw region were on average about $7 \mathrm{~m}$ taller $(23.3 \pm 2.6 \mathrm{~m})$ and ca. $11 \mathrm{~cm}$ thicker (35.7 $\pm 4.5 \mathrm{~cm}$, Fig. 3). Similar differences of the growth parameters were found between Kolari and Kevo. Namely, in the Kevo region, pines at the age 78-95 years were ca. $7 \mathrm{~m}$ smaller $(8.8 \pm 2.1 \mathrm{~m})$ and ca. $11 \mathrm{~cm}$ thinner $(13.6 \pm 4.3 \mathrm{~cm}$, Fig. 3$)$ than in the Kolari region. Similarly, the site index obtained for pine stands in these regions varied by a difference of about $7 \mathrm{~m}$. The highest value of the parameter was found for Wrocław $(24.7 \pm 3.6 \mathrm{~m})$, next for Kolari $(17.7 \pm 1.3 \mathrm{~m})$ and the lowest for the Kevo region $(10.5 \pm 1.5 \mathrm{~m})$. The differences between mean values of the site index among all the studied regions were statistically important (Fig. 4).

\subsection{Effect of soil texture on site index}

The only significantly important correlations between contents of textural soil classes and values of site index were found for the Wrockaw area. In this region, contents of all the fractions $>0.25 \mathrm{~mm}$ were negatively related to site index, while for all the smaller fractions positive, statistically significant $(\mathrm{P}<0.05)$ correlations were consequently found. The strongest relations were stated for the content of the fraction $0.5-0.25 \mathrm{~mm}(-0.353$, $\mathrm{P}<0.001)$ and $0.005-0.002 \mathrm{~mm}(0.334, \mathrm{P}<0.001$; Table 2$)$. The rela-
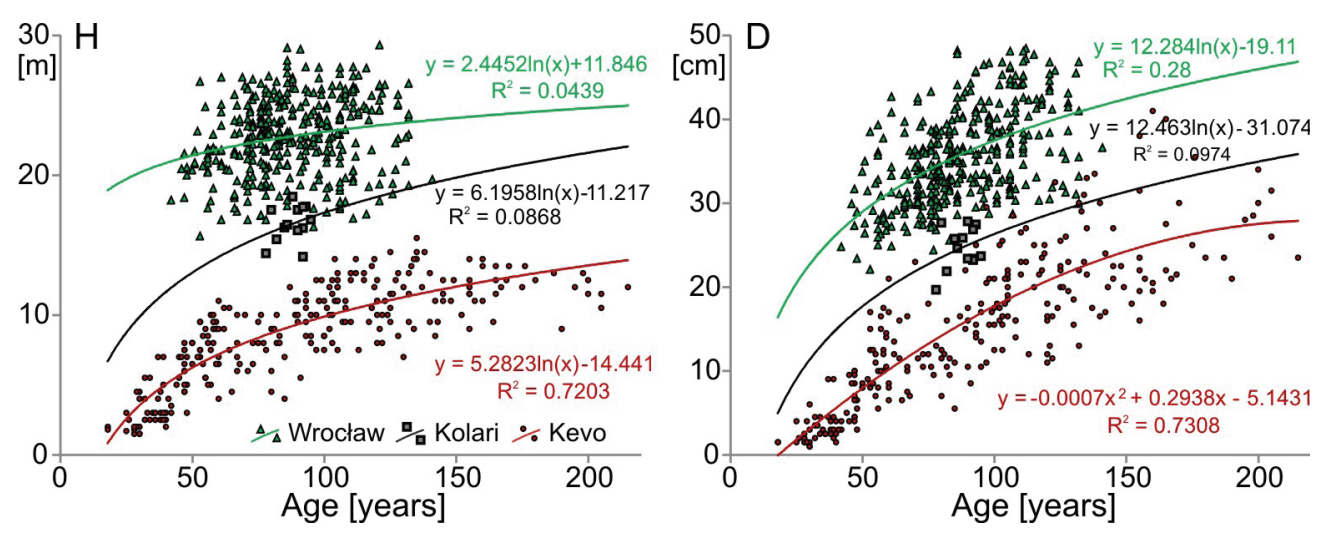

Fig. 3. Relation between age vs. height (H) and age vs. diameter (D) for pine stands investigated in the studied regions. Records shown for Wroclaw and Kolari refer to means obtained from measurements of 10 dominant trees in each even-aged stand while for Kevo to all all-aged trees occurring in a plot located in a stand

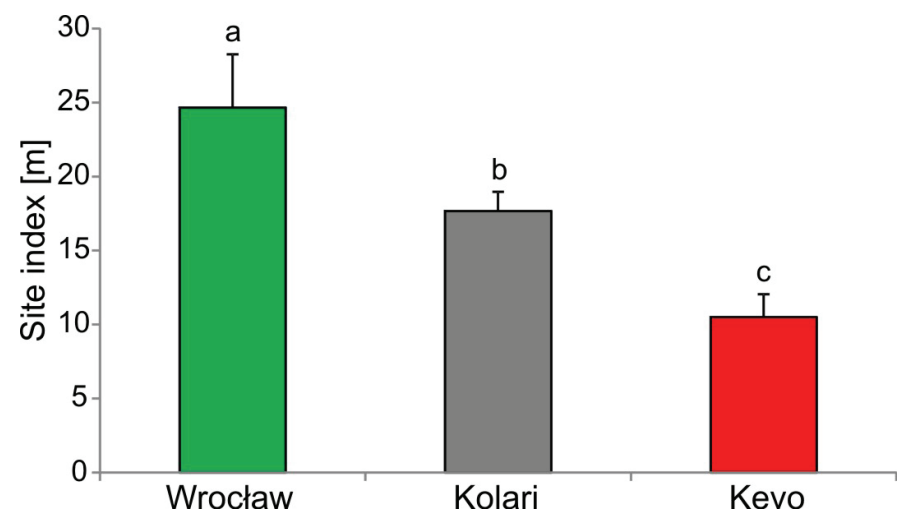

Fig. 4. Mean (+SD) site index of pine stands in the studied regions. Different letters at bars indicate significant difference $(\mathrm{P}<0.01)$ between the regions according to ANOVA RIR Tukey test for uneven size samples

Table 2

Values of the Spearman correlations between site index of pine stands and contents of particular textural classes in the studied plots by regions; in bold significant relations $(\mathrm{P}<0.05)$ are indicated

\begin{tabular}{|c|c|c|c|c|c|c|c|c|c|}
\hline \multirow[t]{2}{*}{ Region } & \multicolumn{9}{|c|}{ Textural classes [mm] } \\
\hline & $>1$ & $1-0.05$ & $0.05-0.25$ & $0.25-0.10$ & $0.10-0.05$ & $0.05-0.02$ & $0.02-0.005$ & $0.005-0.002$ & $<0.002$ \\
\hline Wrocław & -0.09 & -0.19 & -0.35 & 0.18 & 0.24 & 0.31 & 0.32 & 0.33 & 0.19 \\
\hline Kolari & 0.15 & 0.02 & -0.18 & 0.23 & -0.04 & 0.30 & 0.40 & 0.41 & 0.46 \\
\hline Kevo & 0.00 & 0.00 & 0.10 & -0.30 & 0.00 & -0.20 & -0.20 & 0.67 & -0.30 \\
\hline
\end{tabular}


Fig. 5. Relationship between site index of pine stands and content of the $<0.05 \mathrm{~mm}$ soil textural fraction in the Wrocław region

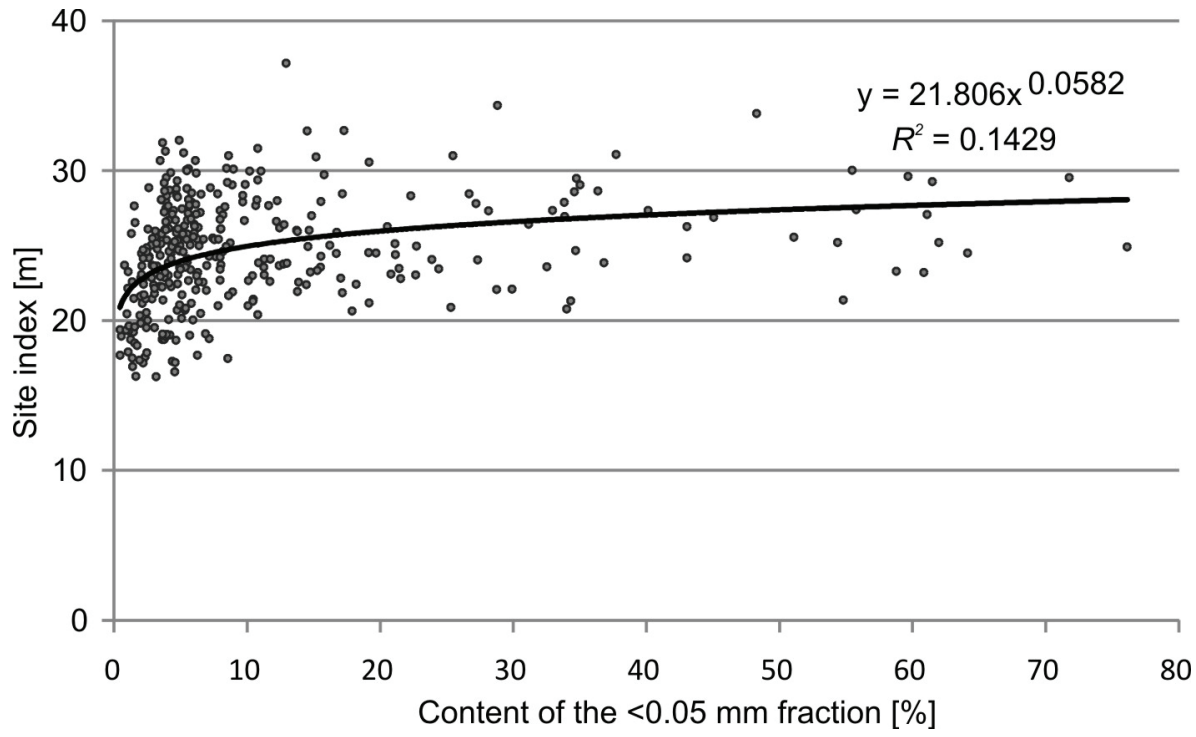

tion between the site index and all the fine-textured fractions (silt and clay: $<0.05 \mathrm{~mm}$ ) was curvilinear. Namely, the strong positive relation was found for relatively low contents of the $<0.05 \mathrm{~mm}$ fraction (up to ca. 15\% content of the fraction), while for middle and high contents the relationship disappeared (Fig. 5). This is clearly reflected in the results of the correlation analysis. Namely, with regard to soils having less than $15 \%$ of the $<0.05$ fraction, the relation between values of the site index and the content of this fraction was clear and significant $(0.35$, $\mathrm{P}<0.001$ ). While for pedons being characterized by the higher content of the fraction, the relation was statistically insignificant $(\mathrm{P}=0.12)$. Contents of all the studied textural fractions were of no importance for site index for both of the investigated Finnish regions.

\section{Discussion}

Close to the boreal timberline, even relatively small differences in temperature can distinctly affect tree growth (e.g. Hustich, 1948; Seo et al., 2010). This well known climatic rule can explain the fact that differences in pine growth parameters between Wrocław vs. Kolari and Kolari vs. Kevo were similar in spite the distance apart, as well as differences in climatic parameters between the two studied Finnish regions were relatively small. Albeit in this preliminary comparative study the number of plots in Finland was enough to determine differences in pine site index between the studied regions, the number was too low to show the possible effect of soil texture on pine growth in the studied Finnish regions. In the northern boreal zone this effect is of course strongly obliterated by the dominant influence of climate conditions, however its hypothetical existence could be examined in possible future studies based on more numerous plots. The effect of soil texture on site index was revealed for Scots pine stands in southern Finland by Tamminen (1993) who showed the positive correlation of the index to the content of fine fractions and negative correlation to the content of stones and gravel.
With decreasing latitudes the importance of climate declines and the significance of water conditions for growth of trees increases (Hustich, 1972). This can be linked to the strong positive relation between contents of fine-textural fractions in sandy soils and site index of Polish pine stands, as stated in this study. Namely, these fractions affect positively not only soil fertility but also, by increasing retention of rainwater, improve water conditions for the existence of trees, which is especially crucial just with regard to sandy ecosystems (e.g. Prusinkiewicz et al., 1980; Binkley and Fisher, 2013). From this point of view, it could be surprising why the positive relation between the content of finetextured fractions and site index found for the Wrocław region did not concern soils characterized by middle and high volume of the fractions. This can likely be explained with two reasons. Firstly, the study concerned the species of rather low demands to soil fertility, thus higher pools of nutrients resulting from relatively high content of fine-textural classes was not reflected in a higher site index. Secondly, in temperate forests the species can grow improperly when is introduced on fine-textured soils, because of the negative effect of such a texture on pine roots (Dzięciołowski, 1963).

Growth dynamics of trees are, of course, related not only to triggers included in this study (climatic and pedogenic conditions), because such agents as e.g. genetic variation within the species as well as thinning intensity can also exert a significant effect on the dynamics. However, the dominant influence of the climatic factor on the stated differences in pine growth between the studied regions was so dominant and clear, that it likely obliterated the existing effect of other agents.

The obtained results gain new data for potential improvement of sustainable forest management in Central Europe. Namely, according to the current Polish instructions for forestry (Klasyfikacja, 2000; Zasady, 2012), it is still permitted to introduce even up to ca. $50 \%$ portion of Scots pine on fine-textured soils. However, the results of this study suggest that Scots pine, as indicated by its height growth, does not fully utilize the relatively high fertility of fine-textured soils, which, in the Wrocław region, is much higher than of sandy pedons (Sewerniak, 2011b). 
Hence, it would be advisable to fully dedicate fine-textured soils for breeding deciduous forests in Central Europe and thus the soils should be primarily designed for full conversion of pine monocultures into broadleaved stands.

\section{Conclusions}

The magnitude of differences in growth parameters of pines growing in particular northern boreal regions can be of a similar scale to the differences between boreal and temperate regions. This highlights the high importance of climate for tree growth close to the northern tree limit. The dominance of the effect of the climatic factor in the northern boreal zone involves the obliteration of the relation between the pine site index and soil texture, as stated for the investigated temperate region. To conclusively examine the possible existence of the relationship in the northern boreal zone, the conducted preliminary research should be expanded to more research plots located in this zone. This study suggests that in temperate European forests Scots pine does not fully utilize the potential fertility of fine-textured soils. Hence, in Central Europe such soils should be primarily designed for full conversion of pine monocultures into broadleaved stands.

\section{Acknowledgments}

The Polish part of the research was financed by the Polish Ministry of Science and Higher Education (project N309 007 32/1037), while the Finnish side was supported by the EU (as a part of the LAPBIAT project). I would like to thank the staff of the Finnish Forest Research Institute Kolari Unit and the Kevo Subarctic Research Institute for their help in field work. I am also grateful to Jolanta Kuszaj for her help in some field and laboratory works and to Dave Beynon for linguistic support.

\section{References}

Binkley, D., Fisher, R.F., 2013. Ecology and Management of Forest Soils. John Wiley \& Sons, Ltd, Chichester.

Bruchwald, A., Kliczkowska, A., 1997. Kształtowanie się bonitacji dla drzewostanów sosnowych Polski (Forming of pine stand quality class in Poland). Prace Instytutu Badawczego Leśnictwa - Seria A 838, 63-73.

Bruchwald, A., Michalak, K., Wróblewski, L., Zasada, M., 2000. Analiza funkcji wzrostu wysokości dla różnych regionów Polski (Analysis of height growth functions for various regions of Poland). [In:] Bruchwald, A. (Ed.), Przestrzenne zróżnicowanie wzrostu sosny (Spatial variation in Scots pine growth)(). Fundacja Rozwój SGGW, Warszawa, 84-91.

Dzięciołowski, W., 1963. Warunki rozwojowe drzewostanów sosnowych na niektórych glebach bielicowych (Conditions of development of pine stands on podzolic soils made of different quaternary sediments). Poznańskie Towarzystwo Przyjaciół Nauk - Prace Komisji Nauk Rolniczych i Komisji Nauk Leśnych 15(1), 3-68.

FAO. 2015. World Reference Base for Soil Resources 2014 (update 2015). International soil classification system for naming soils and creating legends for soil maps. World Soil Resources Reports No. 106, Rome.
Finnish Meteorological Institute. 2008-2009. Ilmastokatsaus.

Franke, A.K., Bräuning, A., Timonen, M., Rautio, P., 2017. Growth response of Scots pines in polar-alpine tree-line to a warming climate. Forest Ecology and Management 399(1), 94-107. https://doi.org/10.1016/ j.foreco.2017.05.027

Gustavsen, H.G., 1980. Talousmetsien kasvupaikkaluokittelu valtapituuden avulla (Site index curves for conifer stands in Finland). Folia Forestalia 454, 1-31.

Henttonen, H.M., Mäkinen, H., Heiskanen, J., Peltoniemi, M., Laurén, A., Hordo, M., 2014. Response of radial increment variation of Scots pine to temperature, precipitation and soil water content along a latitudinal gradient across Finland and Estonia. Agricultural and Forest Meteorology, 198-199, 294-308. https://doi.org/10.1016/ j.agrformet.2014.09.004

Hustich, I., 1948. The Scotch pine in northermost Finland and its dependence on the climate in the last decades. Acta Botanica Fennica 42, $1-75$.

Hustich, I., 1958. On the recent expansion of Scots pine in northern Europe. Fennia 82, 1-25.

Hustich, I., 1972. The influence of climate on the growth of trees. [In:] Vasari, Y., Hyrärinen, H., Hicks, S., (Eds), Climatic changes in arctic areas during the last ten-thousand years. University of Oulu, Oulu, 273-276.

Klasyfikacja gleb leśnych Polski (Classification of forest soils in Poland), 2000. Centrum Informacyjne Lasów Państwowych, Warszawa.

Kenk, G., Guehne, S., 2001. Management of transformation in central Europe. Forest Ecology and Management 151, 107-119. https://doi. org/10.1016/S0378-1127(00)00701-5

Kint, V., Geudens, G., Mohren, G.M.J., Lust, N., 2006. Silvicultural interpretation of natural vegetation dynamics in ageing Scots pine stands for their conversion into mixed broadleaved stands. Forest Ecology and Management 223, 363-370. https://doi.org/10.1016/ j.foreco.2005.11.018

Milewski, W. (Ed.), 2017. Forests in Poland 2017. The State Forests Information Centre, Warszawa.

Olaczek, R., 1976. Zmiany w szacie roślinnej Polski od połowy XIX wieku do lat bieżących (Changes in the vegetation cover of Poland since the middle of XIX century). Zeszyty Problemowe Postępów Nauk Rolniczych 177, 369-408.

Operat glebowo-siedliskowy Nadleśnictwa Oława (Elaboration of forest sites for the Oława Forest District), 2003. Operat s.c., Toruń.

Operat glebowo-siedliskowy Nadleśnictwa Bolesławiec (Elaboration of forest sites for the Bolesławiec Forest District), 2004. Operat s.c., Toruń.

Operat glebowo-siedliskowy Nadleśnictwa Głogów (Elaboration of forest sites for the Głogów Forest District), 2005. Operat s.c., Toruń.

Prusinkiewicz, Z., Bednarek, R., Pokojska, U., 1980. Gleby bielicoziemne w Polsce (The soils of the podsolization-class in Poland). Przegląd Geograficzny 52(1), 103-113.

Seo, J.-W., Salminen, H., Jalkanen, R., Eckstein, D., 2010. Chronological coherence between intra-annual height and radial growth of Scots pine (Pinus sylvestris L.) in the northern boreal zone of Finland. Baltic Forestry 16(1), 57-65.

Sevola, V. (Ed.), 2013. Forest Finland in brief 2013. Finnish Forest Research Institute, Vantaa.

Sewerniak, P., 2011a. Wpływ uziarnienia gleby na bonitację drzewostanów sosnowych w południowo-zachodniej Polsce (The influence of soil texture on the site index of Scots pine stands in south-west Poland). Forest Research Papers 72(4), 311-319. https://doi.org/10.2478/ v10111-011-0005-x

Sewerniak, P., 2011b. Zróżnicowanie wybranych właściwości gleb drzewostanów sosnowych w południowo-zachodniej Polsce (Variability of selected soil properties in Scots pine stands of southwestern Poland). Roczniki Gleboznawcze - Soil Science Annual 62(1), 142-151. 
Spiecker, H., 2003. Silvicultural management in maintaining biodiversity and resistance of forests in Europe-temperate zone. Journal of Environmental Management 67, 55-65. https://doi.org/10.1016/S03014797(02)00188-3

Tamminen, P., 1993. Pituusboniteetin ennustaminen kasvupaikan ominaisuuksien avulla Etelä-Suomen kangasmetsissä (Estimation of site index for Scots pine and Norway spruce stands in South Finland using site properties). Folia Forestalia 819, 1-26.
Woś, A., 2010. Klimat Polski w drugiej połowie XX wieku (Climate of Poland in the second half of the 20th century). Wydawnictwo Naukowe UAM, Poznań.

Zasady hodowli lasu (Instructions for silviculture), 2012. Centrum Informacyjne Lasów Państwowych, Warszawa.

Zerbe, S., 2002. Restoration of natural broad-leaved woodland in Central Europe on sites with coniferous forest plantation. Forest Ecology and Management 167, 27-42. https://doi.org/10.1016/S0378-1127(01)00686-7

\section{Słowa kluczowe}

Drzewostany sosnowe

Uziarnienie gleby

Bonitacja drzewostanu

Klimat

Urzadzanie lasu

Przebudowa monokultur iglastych

\section{Różnice w parametrach wzrostowych sosny zwyczajnej w Polsce i Finlandii: studium porównawcze w nawiązaniu do uziarnienia gleby}

\section{Streszczenie}

Celem pracy było przeanalizowanie różnic w parametrach wzrostowych (wysokość, pierśnica, wskaźnik bonitacji) drzewostanów sosny zwyczajnej (Pinus sylvestris L.) w Polsce i Finlandii w nawiązaniu do uziarnienia gleby. Szczegółowe badania przeprowadzone na 349 powierzchniach badawczych w drzewostanach Regionalnej Dyrekcji Lasów Państwowych we Wrocławiu porównano ze wstępnymi wynikami prac wykonanych w dwóch rejonach położonych w północnej Finlandii (Kolari i Kevo, łącznie 18 powierzchni badawczych). W pracy udokumentowano wielkość różnic w wysokości oraz pierśnicy sosen, a także wskaźniku bonitacji drzewostanów rosnących w trzech odmiennych pod względem klimatu regionach europejskiego zasięgu sosny zwyczajnej. Zależność między wartością wskaźnika bonitacji sosny a zawartością drobnych frakcji uziarnienia stwierdzono jedynie dla powierzchni z glebami piaszczystymi w Polsce. Ze względu na kluczowy wpływ czynnika klimatycznego na funkcjonowanie drzewostanów w warunkach północnej Finlandii, w regionie tym znaczenie tekstury gleby dla parametrów wzrostowych sosny wydaje się marginalne. Z tego względu jednoznaczne określenie występowania potencjalnych zależności pomiędzy cechami uziarnieniem gleby a dynamiką wzrostu drzew w warunkach północnej Finlandii wymagałoby przeprowadzenia szczegółowych badań z większą liczbą powierzchni próbnych. 